\title{
REGREENING OF THE NORTHERN ETHIOPIAN MOUNTAINS: EFFECTS ON FLOODING AND ON WATER BALANCE
}

\author{
Tesfaalem G. Asfaha (1,2), Michiel De Meyere (2), Amaury \\ Frankl (2), Mitiku Haile (3), Jan Nyssen (2) \\ (1) Department of Geography and Environmental Studies, Mekelle University, Ethiopia \\ (2) Department of Geography, Ghent University, Belgium \\ (3) Department of Land Resources Management and Environmental Protection, \\ Mekelle University, Ethiopia
}

\begin{abstract}
The hydro-geomorphology of mountain catchments is mainly determined by vegetation cover. This study was carried out to analyse the impact of vegetation cover dynamics on flooding and water balance in 11 steep (0.27-0.65 m m-1) catchments of the western Rift Valley escarpment of Northern Ethiopia, an area that experienced severe deforestation and degradation until the first half of the 1980 s and considerable reforestation thereafter. Land cover change analysis was carried out using aerial photos (1936,1965 and 1986) and Google Earth imaging (2005 and 2014). Peak discharge heights of 332 events and the median diameter of the 10 coarsest bedload particles ( Max $_{10}$ ) moved in each event in three rainy seasons (2012-2014) were monitored. The result indicates a strong reduction in flooding $\left(R^{2}=0.85, P<0.01\right)$ and bedload sediment supply $\left(R^{2}=0.58, P<0.05\right)$ with increasing vegetation cover. Overall, this study demonstrates that in reforesting steep tropical mountain catchments, magnitude of flooding, water balance and bedload movement is strongly determined by vegetation cover dynamics.
\end{abstract}

KEY WORDS: HYDRO-GEOMORPHOLOGY, REFORESTATION, CREST STAGE, PEAK DISCHARGE, BEDLOAD

\section{Introduction}

The northern Ethiopian highlands have long been subjected to severe land degradation (Hurni, I988; Gebresamuel et al., 2009; Nysen et al., 2015) mainly due to deforestation, overgrazing, impoverishment of the farmers, erosive rains, steep slopes and limited agricultural intensification (Nyssen et al., 2008) as well due to the recurring droughts in the second half of the $20^{\text {th }}$ century. Due to the severity of the degradation, several hydrogeomorphologic features, including dense gully and river networks have developed throughout the region (Frankl et al., 20II; Yitbarek et al., 20I2). In the western Rift valley escarpment in particular, the severity of land degradation is evident in the development of dense gullies and scar networks in the steep slopes transporting high levels of discharge and sediment, including very large boulders, down to the Raya graben. Consequently, devastating flood events claimed the lives of many people and livestock up to the mid-Ig8os. To reverse the problem and specifically protect Alamata town and many villages of the 
Raya graben from flooding, several rehabilitation interventions were initiated in the second half of the ig8os which comprised both physical structures and reforestation measures including the establishment of exclosures on highly degraded steep slopes (Asefa et al., 2003; Nyssen et al., 2010; Nysen et al., 2015) and abandonment of farming and resettlement of people who lived in the severely degraded catchments. In particular the establishment of exclosures (previously degraded areas that are protected from agriculture and grazing to facilitate rapid rehabilitation), have been one of the most effective ways of pursuing vegetation regeneration in the region (Aerts et al., 2003; Descheemaeker et al., 2006). Consequently, the vegetation cover of many of the previously degraded catchments has been improved (Nyssen et al., 2008) (Figure I) which in turn has resulted in several hydrogeomorphologic changes.

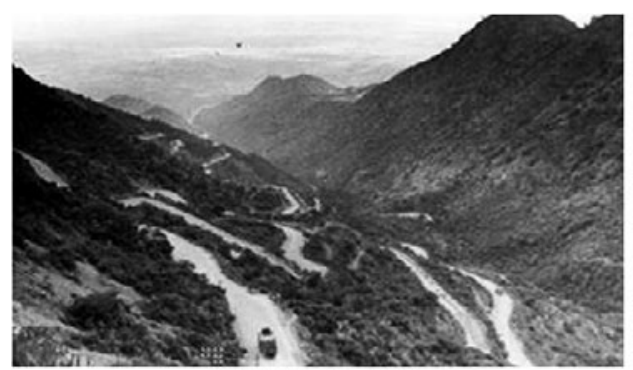

1936Photo@IAO

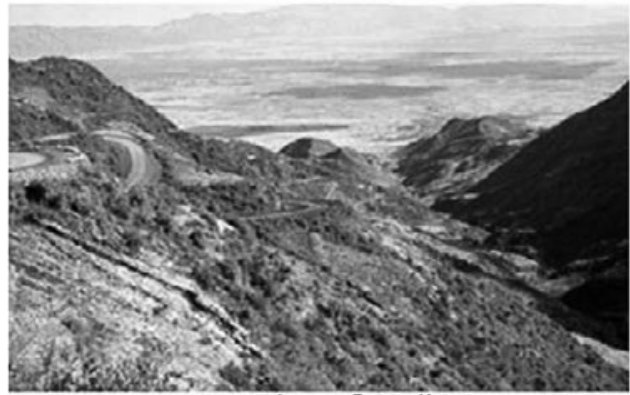

1975 Photo@Neil Munro

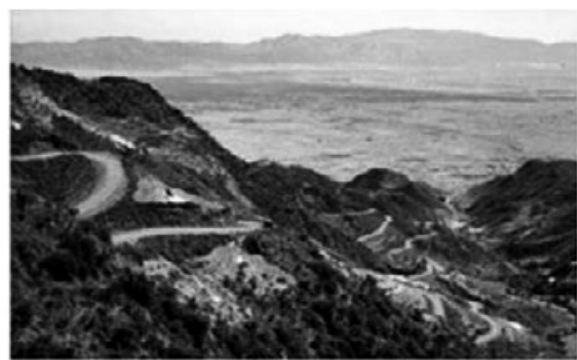

1970 Photo@Larry Workman

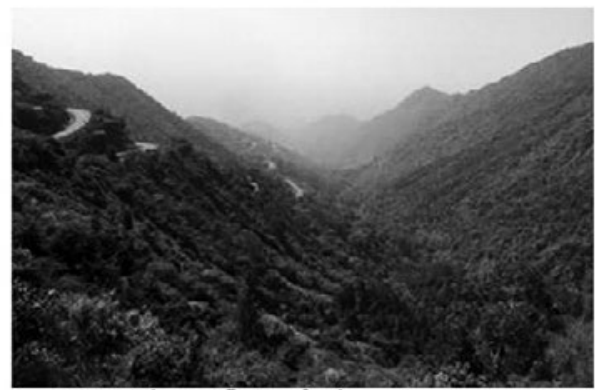

2014Photo@ Tesfaalem G.

Figure 1: Incidental series of repeat photographs of Gira Kahsu catchment shows expansion of agricultural land up to 1975 and dramatic reforestation thereafter.

Many researchers in the region have reported on the role of the improved vegetation cover in reducing the amount of discharge and sediment production from rehabilitated catchments. A study by Descheemaeker et al. (2006) showed a significant reduction in runoff after rehabilitation of small exclosed catchments while Nyssen et al. (2010) reported a reduction of direct runoff volume after catchment management. In their study Frankl et al. (20II) found gully systems to be partially stabilized. However, the impact of changes in vegetation cover on the hydrogeomorphologic characteristics of steep mountain catchments, and particularly on flooding and water balance, has not been sufficiently studied in the western Rift Valley escarpment of Ethiopia. 


\section{Objectives}

The main objective of this study was to analyze the dynamics of flooding and water balance in response to vegetation cover change in the western Rift Valley escarpment of Northern Ethiopia. The study had the following five specific objectives:

- Analysis of the role of reforestation interventions on minimizing land degradation,

- Investigation of land cover changes over the last eight decades (I936-20I4),

- Analysis of variability in peak discharge in relation to spatial rainfall variability, vegetation cover and physiographic factors,

- Analysis of bedload dynamics in relation to peak discharge, vegetation cover, rainfall variability and physiographic factors, and

- Examination of major stream channel adjustments in relation to spatial variability in rainfall distribution, vegetation cover, peak discharge and stream bedload dynamics.

\section{The study area}

The study area consists of a section of the western Rift Valley escarpment of Northern Ethiopia. First, 20 adjacent catchments, which had been severely degraded up to the midI980s and were later reforested to various degrees, were selected for analyzing the role of reforestation interventions in minimizing land degradation in the western Rift Valley escarpment of Northern Ethiopia. Based on the result, II catchments were selected for detail analysis (Figure 2). The catchments contained contrasting vegetation cover (ranging from $4-58 \%$ ), which fully represent the diverse characteristics of the catchments in the western Rift Valley escarpment in terms of vegetation cover, geomorphology, land rehabilitation, settlement and other land uses..
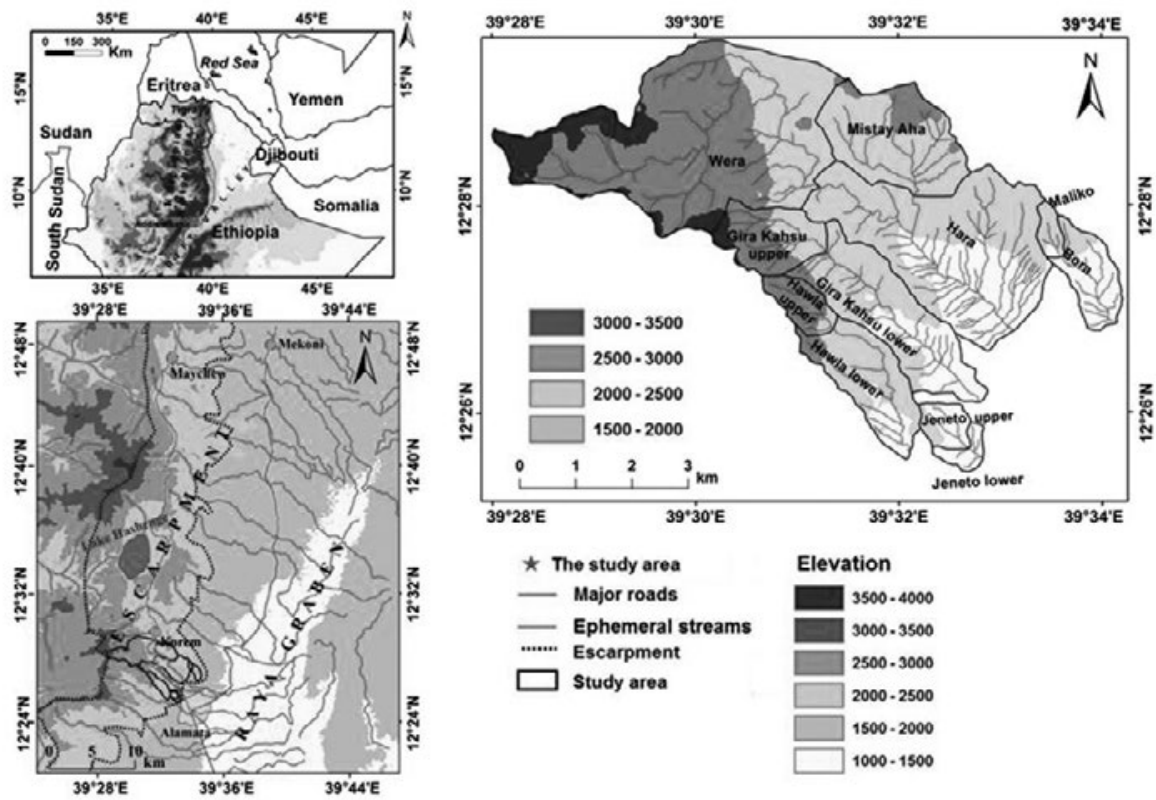

Figure 2: Location map of the study area. 


\section{Location}

The study area ( $\mathrm{I}_{2}{ }^{\circ} 20^{\prime}$ and $\mathrm{I}_{2}{ }^{\circ} 30^{\prime}$ and $39^{\circ} 27^{\prime}$ and $39^{\circ} 35^{\prime}$ ) is found in the Southern zone of Tigray region of Northern Ethiopia on the edge of the western Rift Valley escarpment (Figure I). Specifically, the study catchments are found in Ofla wereda (93\%) and Raya Alamata (7\%) wereda of the southern Tigray region.

\section{Lithology and geomorphology}

The lithology of the study area is composed of Cenozoic volcanic rocks consisting of the Hashenge formation, the Alaje formation and the Aiba basalts (Berhe et al., I987; GSE, I996).

The elevation of the catchments ranges from 1549 to $3140 \mathrm{~m}$ a.s.l., and the average catchment slope gradient ranges from 0.27 to $0.65 \mathrm{~m} \mathrm{~m}^{-1}$. Even at the highest elevations, no frost occurs and there was no glacial or periglacial activity during the Pleistocene (Hendrickx et al., 2015).The escarpment drains towards the east and ephemeral mountain streams turn into braided river systems when reaching the Raya graben floor (Billi, 2007; Biadgilgn et al., 20I5) (Figure 2).

\begin{tabular}{|c|c|c|c|c|c|c|}
\hline \multirow[t]{2}{*}{ Catchment } & \multirow{2}{*}{$\begin{array}{l}\text { Area } \\
\left(\mathrm{km}^{2}\right)\end{array}$} & \multirow{2}{*}{$\begin{array}{l}\text { Slope } \\
\text { gradient } \\
\left(\mathrm{m} \mathrm{m}^{-1}\right)\end{array}$} & \multirow{2}{*}{$\begin{array}{l}\text { Perimeter } \\
(\mathrm{km})\end{array}$} & \multicolumn{3}{|c|}{ Elevation (m a.s.I.) } \\
\hline & & & & Max & Min & Mean \\
\hline Wera & 12.52 & 0.28 & 18.34 & 3140 & 2332 & 2748 \\
\hline Mistay Aha & 3.79 & 0.27 & 8.12 & 2636 & 2282 & 2422 \\
\hline Hara & 24.47 & 0.34 & 28.46 & 3140 & 1592 & 2477 \\
\hline G. Kahsu upper & 1.87 & 0.52 & 5.97 & 3085 & 2099 & 2666 \\
\hline G.Kahsu lower & 5.89 & 0.50 & 14.20 & 3085 & 1705 & 2276 \\
\hline Hawla upper & 0.83 & 0.54 & 3.90 & 2920 & 2299 & 2628 \\
\hline Hawla lower & 3.38 & 0.57 & 9.68 & 2920 & 1856 & 2272 \\
\hline Jeneto upper & 0.62 & 0.58 & 3.16 & 2165 & 1711 & 1910 \\
\hline Jeneto lower & 1.0 & 0.50 & 4.08 & 2165 & 1677 & 1869 \\
\hline Maliko & 0.36 & 0.65 & 2.66 & 2420 & 1884 & 2184 \\
\hline Bora & 1.76 & 0.51 & 6.28 & 2414 & 1549 & 1920 \\
\hline
\end{tabular}

Table 1: Basic topographic characteristics of the catchments.

Soil

The catchments under investigation have five soil types. Eutric Cambislos, Lithic Leptosols, Eutric Regosols, Pellic Vertisols and Eutric Nitosos. Moreover, some parts of the catchments are severely degraded up to the bed rock (MoA, 2003).

\section{Population distribution}

According to the 2007 population and housing census report of the Ethiopian central statistical authority (CSA), Tigray region had a total population of 4,3 16,988 (CSA, 2008). 
This was projected to increase to 5,055,999 by 2015 (CSA, 2013). There is great variability in population size among the administrative zones in the region where in $2007,29 \%$ $(\mathrm{I}, 245,824)$ of the total population was found in the central Tigray zone followed by $23 \%$ $(\mathrm{I}, 006,504)$ in the southern Tigray zone. Excluding the urban areas, Ofla wereda, which constitutes $93 \%$ of the study area is one of the most populous weredas in the southern Tigray region next to Hintalo Wejerat and Raya Azebo Weredas. Similarly, in terms of population density, next to Alage and Endamekoni weredas, Raya Alamata and Ofla weredas (where $7 \%$ and $93 \%$ of the study catchments are found respectively) are the most populous weredas in the zone. These weredas have higher density than the zone itself.

\begin{tabular}{|c|c|c|c|}
\hline \multirow[t]{2}{*}{ Place } & \multicolumn{3}{|l|}{ Population size } \\
\hline & $2007^{a}$ & $2015^{b}$ & Density (person $\left.\mathrm{Km}^{-2}\right)^{\mathrm{c}}$ \\
\hline Tigray regional state & $4,316,988$ & $5,055,999$ & 122 \\
\hline North western Tigray zone & 736,805 & 848,021 & 60 \\
\hline Central Tigray zone & $1,245,824$ & $1,431,672$ & 138 \\
\hline Eastern Tigray zone & 755,343 & 883,860 & 142 \\
\hline Western Tigray zone & 356,598 & 418,756 & 30 \\
\hline Mekelle city special zone & 215,914 & 323,700 & 2960 \\
\hline Southern Tigray zone & $1,006,504$ & $1,149,990$ & 115 \\
\hline Seharti Samre wereda* & 124,340 & 139,479 & 81 \\
\hline Enderta wereda* & 114,297 & 124,784 & 92 \\
\hline Hintalo wejerat wereda* & 153,505 & 172,452 & 89 \\
\hline Alaje wereda & 107,972 & 120,989 & 158 \\
\hline Endamekoni wereda & 84,739 & 93,716 & 153 \\
\hline Raya Azebo wereda & 135,870 & 154,861 & 88 \\
\hline Raya Alamata wereda & 85,403 & 95,094 & 133 \\
\hline Ofla wereda & 126,889 & 138,563 & 128 \\
\hline Maychew/town/wereda & 23,419 & 35,067 & 2166 \\
\hline Korem/town wereda & 16,856 & 25,190 & 2247 \\
\hline Alamata/town/wereda & 33,214 & 49,795 & 3943 \\
\hline $\begin{array}{l}\text { a based on the } 2007 \text { population an } \\
\text { b projections based on the } 2007 \mathrm{pc} \\
\text { c calculated based on the projecte } \\
\text { * these weredas are now in the Sol } \\
\text { census }\end{array}$ & $\begin{array}{l}\text { using census report } \\
\text { tion and housing cens } \\
\text { ulation in column } 3 \text {. } \\
\text { astern Tigray zone wh }\end{array}$ & h report & the 2007 population and housing \\
\hline
\end{tabular}

Table 2: Demographic characteristics of the study area.

\section{Materials and methods}

Analyzing the role of reforestation interventions on minimizing land degradation

As a first approach, analysis of the impact of reforestation interventions on minimizing land degradation was carried out on 20 adjacent catchments by (i) examining the relationship between land degradation as represented by density of scar networks and 
vegetation cover as represented by Normalized Difference Vegetation Cover (NDVI) as well as major topographic variables (slope gradient and slope aspect); and (ii) by identify the major stream channel adjustments occurring in response to catchment scale vegetation cover changes.

The mean NDVI values of each catchment were computed from Landsat satellite image (Thematic Mapper) of 25 December 2010 while all scars on the steep slopes of the 20 catchments were mapped on Google Earth imagery ( $0.6 \mathrm{~m}$ resolution acquired in October 2005) and were processed in GIS to examine the status of land degradation in each catchment. The topographic characteristics of the catchments were computed from a 30 $m$ resolution digital elevation model (DEM). Detail field observation and interviews with local communities were used to identify the major stream channel adjustments that had occurred in response to vegetation cover changes.

Analyzing long term land cover changes over eight decades (1936-2014)

Based on the analysis of the role of reforestation interventions on minimizing land on 20 adjacent catchments, II study catchments with contrasted vegetation cover were selected for detail analysis. Hence, long term land cover change analysis was carried out from both black-andwhite aerial photos (1936, I965 and 1986) and high resolution Google Earth imaging (2005 and 2014) complemented with detail field verifications. The digitization process was carried out on screen using ArcGIS and stereoscopes were used to supplement the mapping process.

\section{Analyzing variability of peak discharge in relation to precipitation variability and vegetation cover \\ - Monitoring precipitation variability}

Peak discharge is an important variable that best explains the hydrological characteristics of mountain streams. Hence, the run off response of the II catchments was analyzed using peak discharge events which were monitored over three rainy seasons (2012-2014) in II stations. In any hydrological analysis, it is crucial to have data on the spatio-temporal distribution of precipitation across catchments (Volkmann et al., 20Io), which is usually done from ground based rain gauge networks (Villarini et al., 2008). Hence, seven nonrecording rain gauges (opening diameter $=20 \mathrm{~cm}$ ) were installed to collect the amount of precipitation events over three years (20I2 - 20I4) (Figure 3). Measurements were made once a day (6:0oPM). The locations of the rain gauges were selected based on geographic spread, topography, altitude and accessibility (WMO, 2008), giving a density of one rain gauge per $5.2 \mathrm{~km}^{2}$. This allowed for accurate representations of spatial variability of rainfall (Volkmann et al., 2010). The station precipitation data were converted in to a daily precipitation map (Villarini et al., 2008) using the Thiessen Polygon method (National Weather Service, I999) and finally, total annual rainfall of the stations and area-weighted average daily precipitation over the catchments $\left(\mathrm{P}_{d}\right)$ were calculated. The precipitation events together with vegetation cover of 2014 were used to explain the variability in runoff of response of the catchments. 


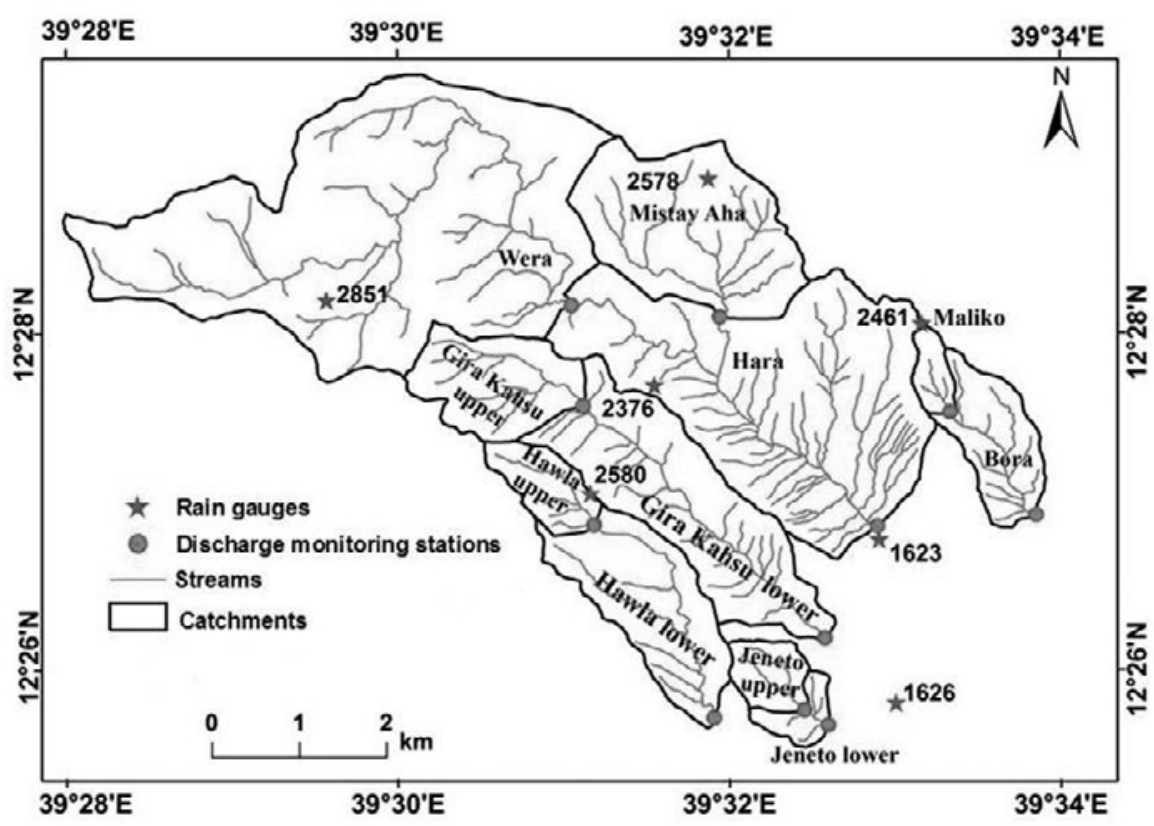

Figure 3: Monitoring stations for rainfall, peak discharge and bedload.

\section{- Calculation of peak discharge}

Runoff response of catchments can be directly measured in different conventional ways. In the case of mountainous streams, however, direct measurement during the floods presents many challenges mainly due to the flash rate of the flow and its destructive character (WMO, 2008; Lumbroso and Gaume, 20I2). Hence, it is frequently impossible or impractical to measure the peak discharges when they occur because of conditions beyond human control (Rantz, I982). When such conditions occur, peak discharges in steep mountain streams are indirectly estimated after floods (Lumbroso and Gaume, 2012). In the current study, peak stage discharges were measured in the rainy seasons of 2012, 2013 and 2014 using II crest stage gauges (Waltermeyer, 2008) (Figure 4) which were installed in the outlets of the catchments.

The peak stage data were collected after runoff events (Figure 5). Each station was visited at least once a week on a rotational basis whereby recorded peak stage was associated with the largest precipitation event in the intervening period and a total of 332 measurements were carried out. Based on the daily peak stage data, peak discharge events were computed using the Manning's equation which is the most commonly used hydraulic technique for estimating open channel flow for uncalibrated section (Jarrett, I984; Lumbroso and Gaume, 20I2; Karalis et al., 2014): 


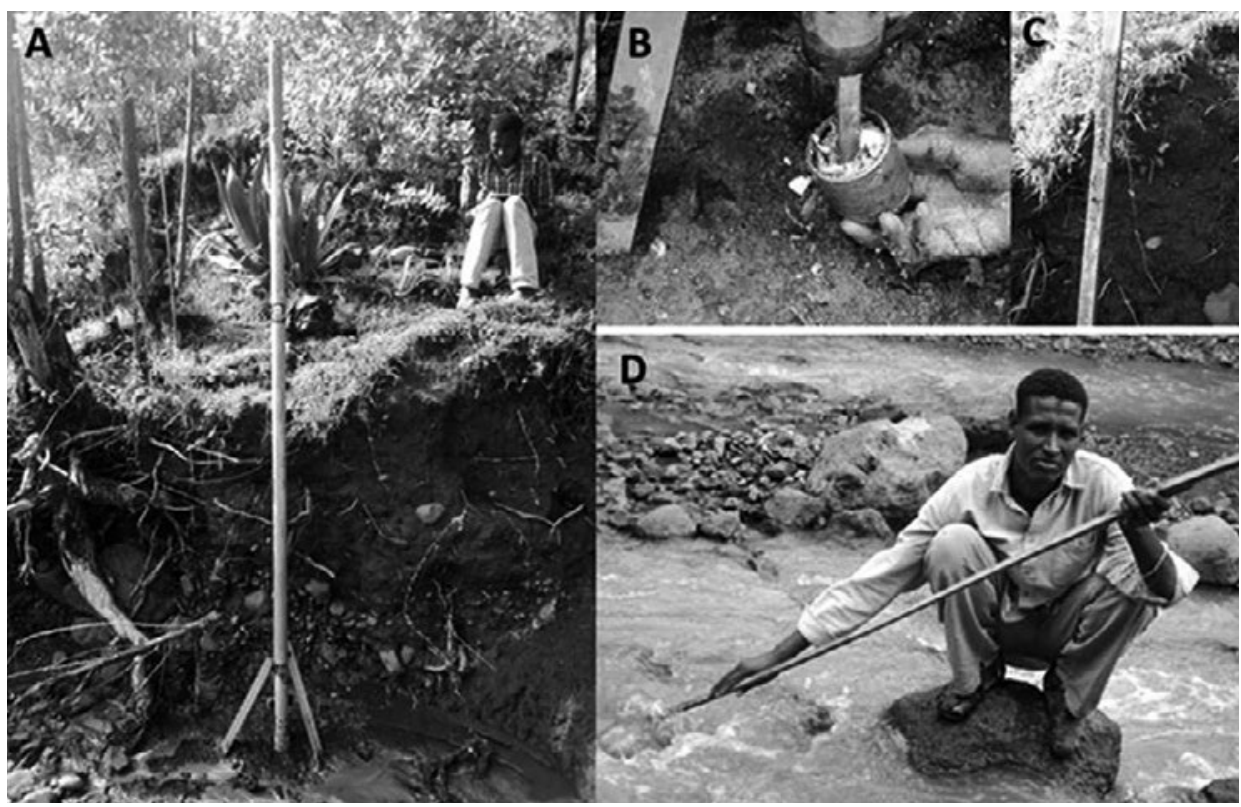

Figure 4: Crest stage gauge (A), sawdust being placed in the bowl of the lower cap before and after measuring peak stage (B), remnants of sawdust on wood staff indicating the highest peak stage of the flood (C), and wood staff being cleaned for the next flood (D).

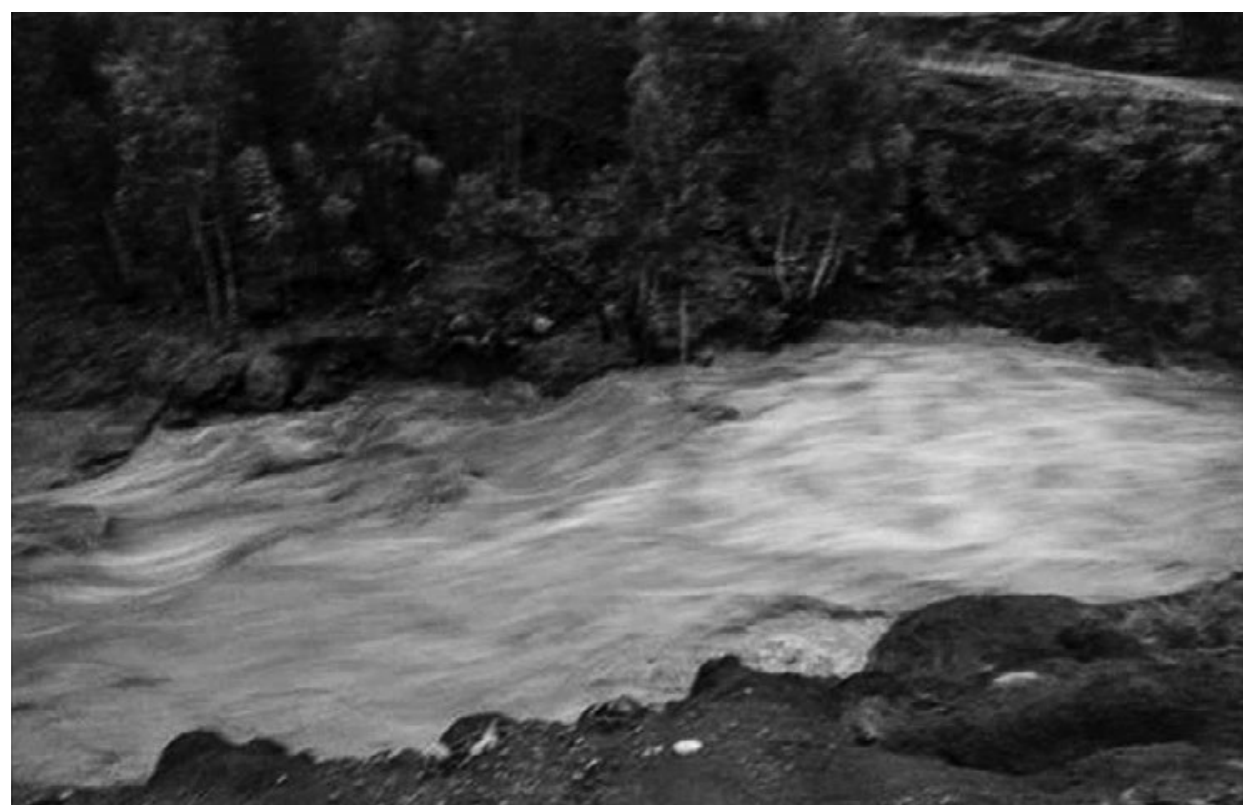

Figure 5: Intensive rainfall event of $21.1 \mathrm{~mm}$ (occurred in a very short period) in Wera' catchment (23/8/2013) produced a strong flash flood of $128 \mathrm{~m}^{3} \mathrm{~s}^{-1}$ at the monitoring station. Crest stage gauge appears in the middle of the opposite bank. 
Analyzing bedload supply and movement

The rapid, deep, turbid, and turbulent character of the flows, as well as large roughness elements and uneven bed topography usually make direct measurement of bedload transport in mountain streams very difficult (Wohl, 2000). In this study, due to the flash nature of the stream flows and the fact that peak discharges usually occur in the late afternoon or at night, variability in bedload supply and entrainment were studied by measuring the size of the ro coarsest bedload particles (Maxio) moved by peak discharge events.

Benchmarks were painted on largest bed materials, which are relatively stable, or bed rock outcrops which hardly move by runoff as reference points. Photographs were taken before and after peak flow event from fixed direction and are used to identify the new bedload particles deposited inside the polygons delimited by benchmarks (Figure 6). The average intermediate diameters of the newly deposited ro coarsest bedload particless (Maxio) were measured in situ using a tape measure. To avoid measurement errors and bias, an average of five measurements were taken per stream bed particle. While we tried to take vertical photographs (to facilitate measurement via photo) by positioning a camera directly over the areas between the painted large boulders, we found that in the lower stations where the stream cross-sections were wider (up to 30 meters in Hara station), it was difficult to take vertical photos and this led to significant distortions. Moreover, some materials were obscured by overlying grains and grass (Church et al., I987). Hence, only in situ measurements were used for the sake of accurate measurements while the photos were used to identify the newly moved bedload particle in peak discharge events.
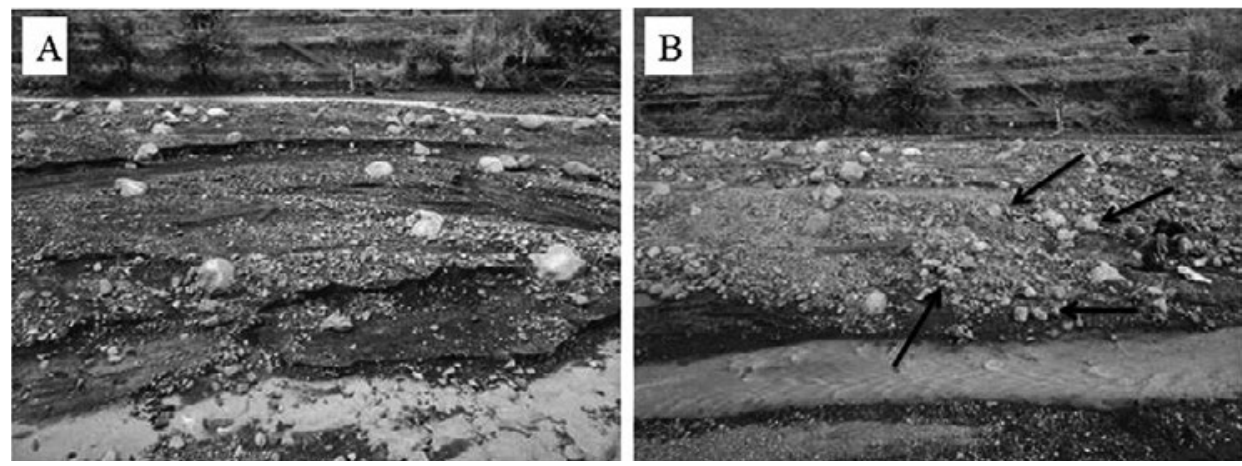

Figure 6: Hara monitoring station: photographs of bed materials (A) taken before (photographed on 19/7/2012) and (B) after a flood event (re-photographed on 20/7/2012). Black arrows indicate some of the new coarsest bed load particles moved, blue arrows indicate crest stage gauge and red arrows indicate tape meter (diameter $=20 \mathrm{~cm}$ ) used as a scale for the size of the bedloads moved.

In addition, in order to analyze the characteristics of the stream bed particles at the monitoring stations, stream bed particle sampling was carried out using the Wolman's (I954) pebble count method, which is the most widely used and the most efficient technique (Harelson et al., 1994). Stream bed particles were sampled systematically at every $30 \mathrm{~cm}$ interval both before and after the rainy season (Figure 7). 

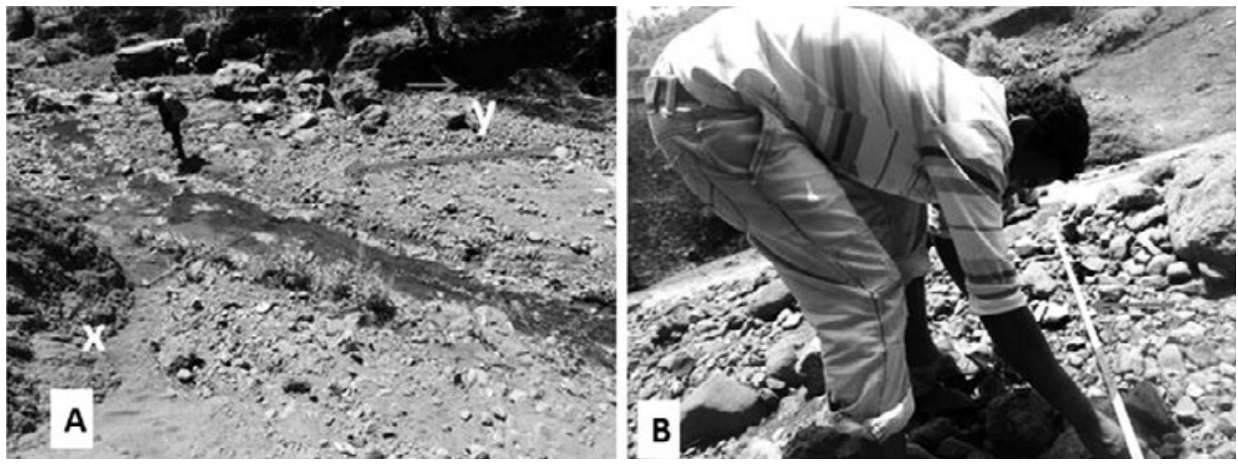

Figure 7: Systematic pebble counting in Wera' station; measuring tape stretched along the stream (A), $x$ and $y$ indicate painted benchmarks for starting the pebble count before and after the rainy season. An assistant researcher, measuring the stream bed particles at every $30 \mathrm{~cm}$ interval (B).

Finally, the average size of the ro coarsest bedload particles (Maxio) moved in each peak discharge event was explained by various biophysical and hydraulic variables such as vegetation cover of the catchment, scar density, average catchment slope gradient, catchment area, hypsometric integral, as well as by hydraulic variables such as peak discharge $(\mathrm{Qp})$, stream power $(\Omega)$ and critical shear stress $(\tau c)$.

Analysis of stream channel geomorphologic changes over eight decades (1936-2014)

Stream channel geomorphologic adjustments were analyzed by mapping the geomorphologic changes of stream channels using aerial photos (1936, 1965 and 1986) and Google Earth images (2005 and 2014) as well as field measurements. The changes were explained in relation to vegetation cover changes, peak discharge and other biophysical variables. Investigation of active and inactive stream channels; boulder bars, abandoned channels, terraces, incised channels as well as changes in the width of the stream channels were carried out for the main streams of the II catchments during the detail geomorphological survey. Locations of the major geomorphologic changes were collected using hand held Garmin Global Positioning System (GPS) (resolution $=7 \mathrm{~m}$ ) and were mapped using the 2005 and 2014 Google Earth images (0.6 m resolution). Local informants who have knowledge about the historical changes in the vegetation cover and its impact on flooding and boulder supply to the streams were involved during the field campaign. Channel morphological changes were monitored over three years (2012-20I4) at the outlets of the eleven stations selected for monitoring of peak discharge and bedload particle movement. 


\section{Results and discussion}

The implications of integrated catchment rehabilitation on minimizing land degradation

Analysis of the level of land rehabilitation in 20 adjacent catchments by correlating density of scar networks (mapped on Google Earth imagery of 2005) and vegetation cover as represented by Normalized Difference Vegetation Index (NDVI) reveals that the density of scar networks was negatively related to NDVI $\left(\mathrm{R}^{2}=0.28, \mathrm{p}<0.0 \mathrm{I}\right)$ and positively with the steepest slope gradients of catchments $(>60 \%)\left(R^{2}=0.21, p<0.05\right)$ (Figure 8). Generally, this result indicates that the reforestation intervention which led to improvements in vegetation cover contributed to the reductions in the levels of degradation of the catchments, whereas the positive relationship between the density of scar networks and slope gradient shows the highest susceptibility of steep mountain catchments to land degradation (Tesfaalem et al., 20I6).

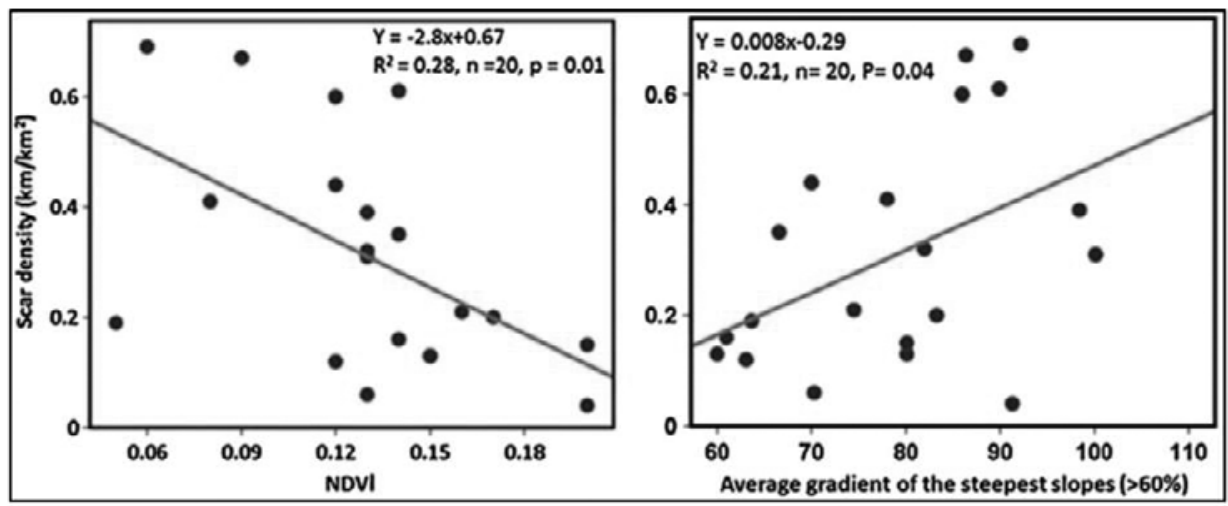

Figure 8: Relationship between Normalized Difference Vegetation Index and scar density (left) and between average gradient of the steepest slopes (>60\%) and scar density (right).

Given that such steep catchments need time to fully recover from the impact of severe degradation, some of the scar networks in the catchments with relatively less vegetation cover still remain as relics on the slopes, being overgrown by vegetation. This is commonly observed in the catchments which are not exclosed from the reach of both human beings and livestock. In the Gira Kahsu catchment, a catchment from where flow of huge discharge and sediment volumes caused devastative flooding of the Raya Graben and in Alamata town in particular, the scars have almost disappeared due to the establishment of exclosures in most part of the catchment. This implies that when steep catchments are freed from the reach of human beings and livestock, the rate of rehabilitation becomes faster.

The analysis of historical aerial photos also indicated that in the I930s, the density of scar networks was much less than in 20I4. Though it was not possible to map the scar networks for 1965 and 1986 due to the low resolution of the aerial photographs, it could be understood that the density of scar networks could have been much more than the scar 
density in 2014 before they recovered owing to increasing forest cover. This is strengthened by the fact that the density of scar network in Gira Kahsu lower catchment was higher in 1936 (0.14 $\mathrm{km} \mathrm{km}^{-2)}$ than in 2014 (0.04 $\mathrm{km} \mathrm{km}^{-2}$ ).

\section{Long term dynamics of land cover}

The long term land cover change analysis using the aerial photos of 1936 , I965 and 1986 as well as Google Earth imageries of 2005 and 2014 (Figure 9) revealed two important periods of land cover change in the study area, (i) rapid deforestation between 1965 and the early I980s and (ii) remarkable improvement of vegetation cover after 1986.
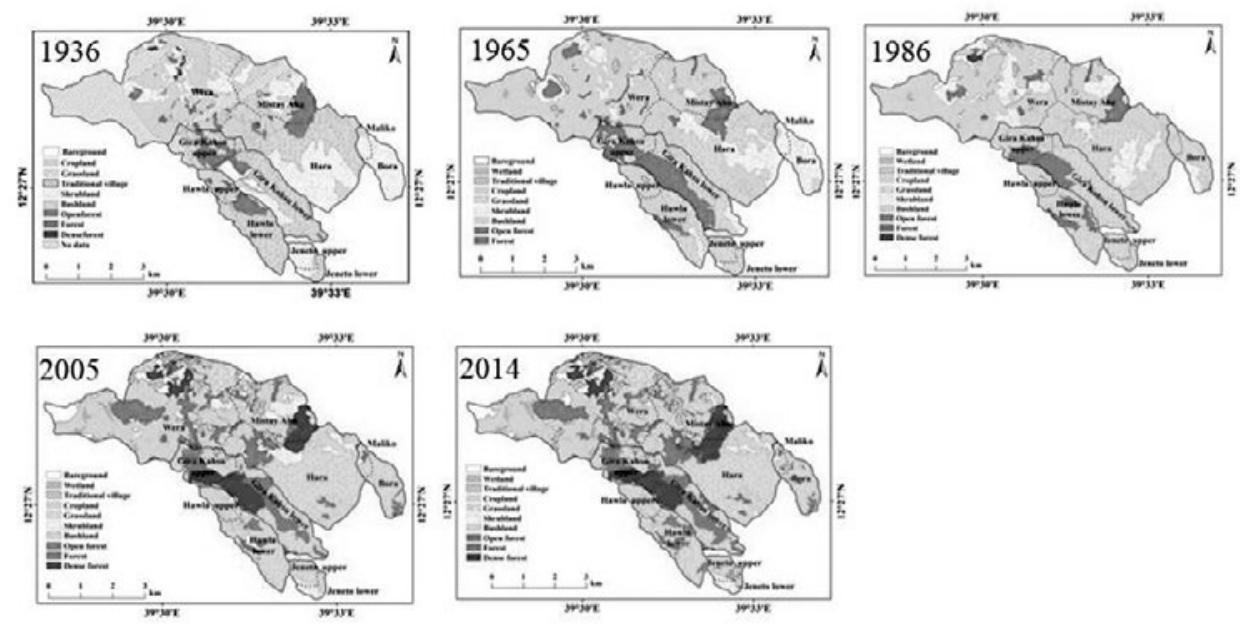

Figure 9: Long term land cover maps (1936-2014).

Bushland was the dominant land cover class in the I930s. Cropland became the dominant land cover between the ig6os and first half of the ig8os. Due to the reforestation interventions initiated in the second half of the I980s, forest cover increased from $9 \%$ in 1986 to $23 \%$ in 2005 and $27 \%$ in 2014 . Total woody vegetation cover (forest, bushland and shrubland) increased from $52 \%$ in 1986 to $62 \%$ in 2005 and 20I4. On the other hand, the proportion of cropland decreased from 43\% in 1986 to $31 \%$ in 2005 and 2014. Although the 1936 aerial photos did not fully cover the study area, it appears that vegetation cover was better than in 1965 and 1986 . Woody vegetation cover was $65 \%$ in 1936 , $48 \%$ in $1_{9} 65$ and $52 \%$ in 1986 . Particularly, Gira Kahsu upper and Gira Kahsu lower were the catchments which showed remarkable improvement in vegetation cover after the second half of the ig8os (chapter three) owing to the integrated reforestation activities and establishment of exclosures in these catchments.

Therefore, this study demonstrates the role of reforestation interventions in rehabilitating severely degraded catchments over a relatively short period of three decades even in steep mountain regions with high rainfall variability. 
Variability of peak discharge in relation to rainfall variability and land cover change

Variability in discharge typically depends on precipitation variability, vegetation cover change, and local topographic factors (Begueria et al., 2006). Owing to their steep slope gradients and high intensity of rainfall, mountain streams are usually characterized by instantaneous and extreme peak discharges which are usually associated with destructive torrents and floods (Ruiz-Villanueva et al., 2010). In this study, the peak discharge analysis based on the 322 events was in line with the findings by Garcia-Ruiz et al. (2008) and many other studies in mountainous areas. The results showed a strong positive linear relationship between rainfall and peak discharge events in all the catchments $\left(R^{2}=0.32\right.$ - 0.94). On the other hand, an exponentially negative relationship was observed between catchment-specific peak discharge coefficient and percentage of vegetation cover (forest and grass) ( $\mathrm{R}^{2}=0.85, \mathrm{p}<\mathrm{0.01}$ ) (Tesfaalem et al., 2015a). Unlike in many flat lands, the catchment-specific peak discharge coefficient was also negatively related to relative distance of vegetation cover from the thalweg $\left(\mathrm{R}^{2}=0.55, \mathrm{p}<0 . \mathrm{or}\right)$ (Figure Io) and with a combined index of vegetation cover and its relative distance from the thalweg $\left(\mathrm{R}^{2}=\right.$ $0.76, \mathrm{p}<0.0 \mathrm{I})$. This shows that, in such steep catchments, if the steepest parts of the catchments are reforested, runoff is effectively buffered long before it reaches in the thalweg, hence, both the percentage of vegetation cover and its location on the upper steeper slopes have significant impact on runoff response of steep mountain catchments.
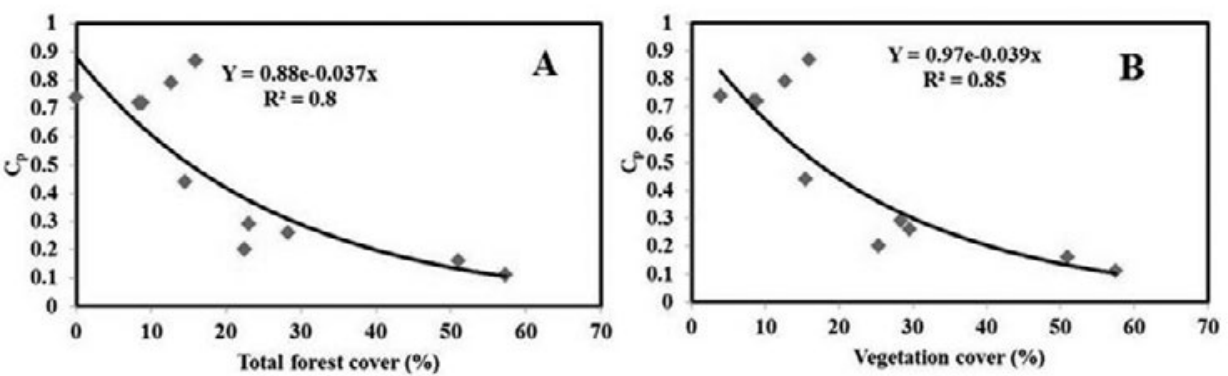

Figure 10: Negative exponential relationship between (A) percentages of total forest and (B) vegetation cover, with catchment-specific discharge coefficient $\left(C_{p}\right)$.

\section{Variability in bedload supply and movement in relation to rainfall variability and land cover change}

Variability in the supply and movement of stream bedload is the other hydro-geomorphologic characteristic of mountain catchments usually associated to storm events. In this study, variability in bedload supply and movement was analyzed along with the peak discharge event by field measurements of the median diameter of the ro coarsest bedload particles (Maxio) moved in each event $(n=332)$ and by measuring the $\mathrm{D}_{5} \mathrm{O}$ and $\mathrm{D} 84$ of the bedload particles using Wolman's stream bed particle sampling method ( $\mathrm{n}=\mathrm{I00}$ ) before and after the rainy seasons (July - September) over the last three years (20II-20I4). Moreover, hydraulic competence analysis was carried out using peak discharge, stream power and critical shear stress approaches. 
Generally, in this study it was demonstrated that the supply of stream bedload in steep mountains is determined negatively by forest cover $\left(\mathrm{R}^{2}=0.60, \mathrm{p}<0 . \mathrm{oI}\right)$ or vegetation cover $\left(R^{2}=0.58, p<0.0 I\right)$ and positively by the average density of scar networks in the sloping catchments $\left(\mathrm{R}^{2}=0.50, \mathrm{p}<0.0 \mathrm{I}\right)$ and catchment size $\left(\mathrm{R}^{2}=0.36, \mathrm{p}<0 . \mathrm{oI}\right)$ while the movement of bedload particles in the stream channels is highly controlled by peak discharge $(\mathrm{Qp})\left(\mathrm{R}^{2}=0.60, \mathrm{p}<0.0 \mathrm{I}\right.$, stream power $(\mathrm{W})\left(\mathrm{R}^{2}=0.7 \mathrm{I}, \mathrm{p}<0 . \mathrm{oI}\right)$ and critical shear stress $(\tau c)$ with reference to $\mathrm{D}_{50}(\mathrm{r} 50)\left(\mathrm{R}^{2}=0.96, \mathrm{p}<0.0 \mathrm{I}\right)$ and D84 $(\mathrm{r} 84)\left(\mathrm{R}^{2}=\right.$ o.93, p < o.or) (Tesfaalem et al., 20I5b) (Figure II).
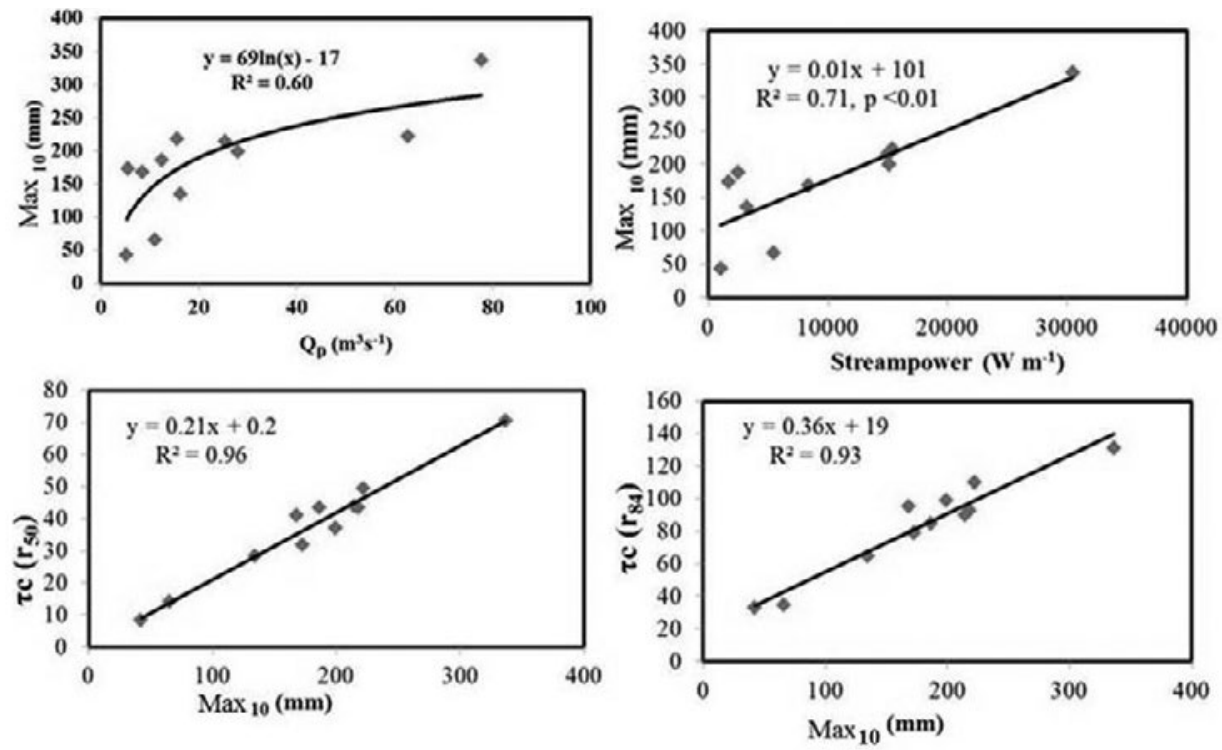

Figure 11: Relationship between average diameter of the 10 coarsest bedload particles moved (Max10) and Peak discharge(Qp), Stream power (W ), critical shear stress with a reference of D84 ( $\tau$ c r84) and critical shear stress with a reference of D50 ( $\tau$ c r50).

\section{Adjustment of mountain stream channels in response to discharge and sediment supply}

In line with the Schumm's (1956) theoretical work, the spatio-temporal variability in peak discharge and bedload occurred over the last eight decades was strongly associated with stream geomorphologic adjustments. In the I930s, stream channels were relatively narrow, sinuous and stabilized with vegetation. Due to higher peak discharge and bedload supply, stream channels became wider, straight and braided between I965 and I986 whereas after the second half of the I980s, the channels gradually returned to being narrow, sinuous and single thread due to reductions in discharge and bedload supply in relation to restoration of the vegetation cover. Between 2012 and 20I4, the streams incised (Figure I2) on average by $6 \mathrm{~cm}$ year $^{-1}$. Stream bed incision was positively related to average peak discharge $\left(\mathrm{R}^{2}=0.7 \mathrm{I}, \mathrm{p}<0.05, \mathrm{n}=\mathrm{II}\right)$. 

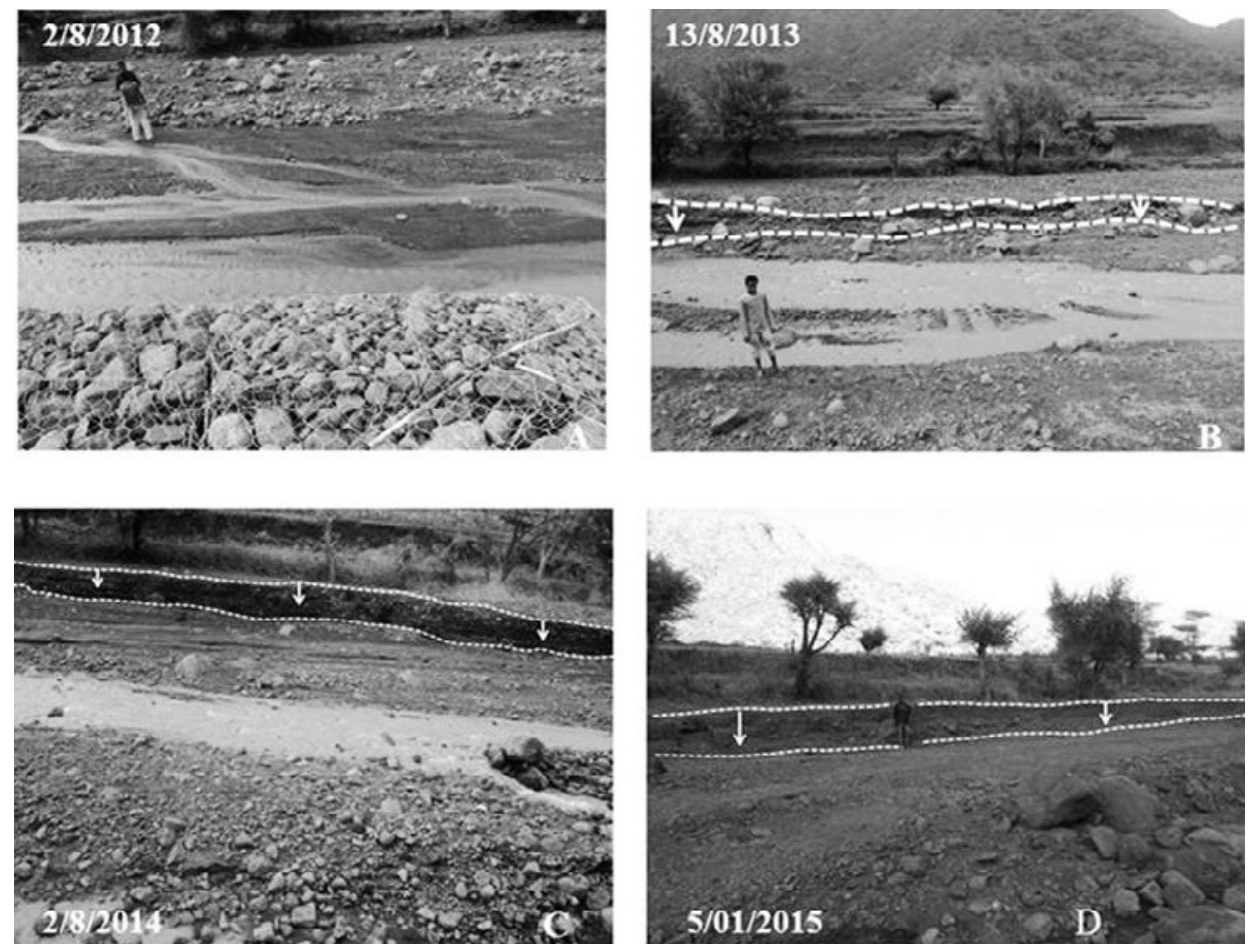

Figure 12: The river Hara stream bed at station was incised on average by $26 \mathrm{~cm}$ between $2 / 8 / 2012$ and $13 / 8 / 2013$ and by $73 \mathrm{~cm}$ between $2 / 8 / 2012$ and 05/01/2015. The capacity of the stream flow is now weak to transport the big boulders (D).

The positive relationship between stream incision and peak discharge as well as the negative relation between peak discharge and vegetation cover implies that nowadays, the peak discharge flow is carrying less bedload and hence, the relatively clear water is degrading the stream bed (Boix-Fayos et al., 2007). By 20I4, the width of the active channel of 4 of the II streams narrowed to $39 \%$ of the width of the flood plain. Moreover, most of the bars which were mainly formed by the supply of big boulders up to the first half of the Ig80s are now stabilized by vegetation.

\section{Conclusion and recommendations}

Conclusions

Overall, based on the findings of the study, the following conclusions were drawn.

Catchment reforestation in the steep mountain catchments of the western Rift Valley escarpment of northern Ethiopia has led to a remarkable stabilization of the slopes in less than 30 years, as well as to a narrowing and incising of rivers that should be interpreted as signs of resilient catchments.

In steep mountainous catchments where it is difficult to directly measure peak discharges using the conventional techniques, given that daily rainfall events generally occur as 
short intensive storms, the hydrological behavior of such mountains could be successfully understood using simple measurements of daily rainfall and peak discharge events. The hydrologic behavior of reforesting steep mountain catchments is determined by precipitation events and strongly by percentage of vegetation cover and its strategic location; farther from the thalweg in the sloping sides of the catchment where vegetation cover buffers volume and velocity of run off before it reaches a drainage line. Daily rainfall events strongly determine peak discharge but its relative influence decreases with increasing vegetation cover.

The availability and supply of bedload in steep mountains is determined negatively by forest or vegetation cover and positively by the presence of scar networks in the steepest part of the catchments. The movement of bedload in the stream beds is highly explained by peak discharge, stream power and strongly by critical shear stress.

In steep mountain streams where direct measurement of bedload transport is difficult, field measurement of the coarsest bedload particles moved after every peak discharge event enables the analysis of variability of bedload flux.

Analysis of variability in bedload supply and movement using simple in situ measurement of the coarsest bedload particles moved in each peak discharge event allows reconstructing historical flood events, if bedload transport conditions are understood.

Steep mountain stream channels quickly adjust to changes in vegetation and associated peak discharge and bedload supply.

\section{Recommendations}

In line to the findings of this research, we make the following recommendations.

Reforestation interventions in steep mountain catchments could strongly decrease flooding and transport of bedload to fertile and densely populated lower areas; this control of deforestation-related environmental calamities occurred furthermore in a relatively short time. Hence, the reforestation activities should continue in the catchments which still have insufficient vegetation cover. Moreover, the strict follow-up of the already reforested areas should continue so that the sustainability of the reforestation process continues.

As recommended previously by Nyssen et al. (2008) and Descheemaeker et al. (2006) based on their studies in a nearby area and as confirmed in this study, priority in reforestation interventions should be given to the steepest parts of catchments, where runoff can be buffered before it enters the drainage system.

In case of catchment management and reforestation activities, down river cutting in the lower part of the catchment may lead to bank failures. Infrastructure planning should anticipate such hydrogeomorphological changes.

The study area is very suitable for the demonstration of the effects of rehabilitation, particularly the Gira Kahsu catchment that is easily accessible and where vegetation changes were strongest. Available material, historical photographic documentation, strong correlations and directly observable field evidence can be the base for educational tours. Equipping the Gira Kahsu catchment with didactic boards could be another component of such a demonstration programme. 


\section{References}

Aerts, R., November, E., Behailu, M., Deckers, J. A., Hermy, M., and Muys, B., 2003. Forest rehabilitation: one approach to water conservation in Central Tigray. Ethiopian Journal of Water Science and Technology 6(I), 34-37.

Asefa, D.T., Oba, G., Weladji, R.B., Colman, J.E., 2003. An assessment of restoration of biodiversity in degraded high mountain grazing lands in northern Ethiopia. Land Degradation and Development I4, 25-38. DOI: IoDio02/ldr.505.

Begueria, S., López-Moreno, J.I., Gómez-Villar, A., Rubio, V., Lana-Renault, N., García-Ruiz, J.M., 2006. Fluvial adjustments to soil erosion and plant cover changes in the Central Spanish Pyrenees. Geografiska Annaler. Series A. Physical Geography, 88 A: I7I-I86.

Berhe, S.M., Desta, B., Nicoletti, M., Teferra, M., I987. Geology, geochronology and geodynamic implications of the Cenozoic magmatic province in western and southwestern Ethiopia: J. of the Geol. Society London I44, 213-226.

Biadgilgn, D., Frankl, A., Mitiku, H., Nyssen, J., 2015. Biophysical controlling factors in upper catchments and braided rivers in drylands: the case of marginal graben of the Ethiopian Rift Valley. Land Degradation and Development: DOI: Io.Ioo/lde.2357

Billi, P., 2007. Morphology and sediment dynamics of ephemeral stream terminal distributary systems in the Kobo Basin (northern Welo, Ethiopia). Geomorphology 85, 98-II3.

Boix-Fayos C, Barbera G, López-Bermúdez F, Castilo M. 2007. Effects of check dams, reforestation and land-use changes on river channel morphology: case study of the Rogativa catchment (Murcia, Spain). Geomorphology 9I, 103-I23.

Church, M.A., McLean, D.G., Wolcott, J.F., I987. River bed gravels: sampling and analysis . In: sediment Transport in Gravel-bed Rivers (C.R. Thorne, J.C. Bathurst, and R.D. hey eds.). John wiley and Sons, New York. pp. 43-70.

CSA (Central Statistical Authority) .2008. Summary and statistical report of the 2007 population and housing census-population size by age and sex. Federal Democratic Republic of Ethiopia Central Statistical Agency, Addis Ababa, December.

CSA (Central Statistical Authority).2013. Population projection of Ethiopia for all regions at wereda level from 2014-2017. Federal Democratic Republic of Ethiopia Central Statistical Agency, Addis Ababa, August.

Descheemaeker, K., Nyssen, J., Rossi, J., Poesen, J., Mitiku, H., Moeyersons, J., Deckers, J., 2006. Sediment deposition and pedogenesis in exclosures in the Tigray Highlands, Ethiopia. Geoderma I32, 29I-3I4.

Frankl A, Nyssen J, De Dapper M, Haile M, Billi P, Munro R.N., Deckers J, Poesen J. 20Ir. Linking long-term gully and river channel dynamics to environmental change using repeat photography (Northern Ethiopia). Geomorphology I29: 238-25I.

Garcia-Ruiz, J.M., Regues, D., Alvera, B., Lana-Renault, N., Serrano-Muela, P., Nadl-Romero, E., Navas, A., Latron, J., Martı-Bono, C., Arnaez J., 2008. Flood generation and sediment transport in experimental catchments affected by land use changes in the central Pyrenees. Journal of Hydrology. 356, 245-260.

Gebresamuel, G., Singh, B.R., Nyssen, J., Borrosen, T., 2009. Runoff and sediment-associated nutrient losses under different land uses in Tigray, Northern Ethiopia. Journal of Hydrology. 376 (I-2), $70-80$.

GSE (Geological Survey of Ethiopia). 1996. Geological map of Ethiopia.Geological Survey of Ethiopia. Addis Ababa, Ethiopia.

Harrelson, C.C., Rawlins, C.L., Potyondy, J.P., I994. Stream channel reference sites: an illustrated guide to field technique. Gen. Tech. Rep. RM-245. Fort Collins, CO: U.S. Department of Agriculture, Forest Service, Rocky Mountain Forest and Range Experiment Station. 6r p. 
Hendrickx, H., Jacob, M., Frankl, A., Nyssen, J. 2015. Glacial and periglacial geomorphology and its paleoclimatological significance in three North Ethiopian Mountains, including a detailed geomorphological map. Geomorphology 246, I56-I67.

Hurni, H. 1988. Degradation and conservation of the resources in the Ethiopian highlands. Mountain research and development 8, I23-130.

Jarrett, R.D., I984. Evaluation of methods estimating palaeo floods on high-gradient streams. (Paper presented at the American Geophysical Union Fall Meeting, San Francisco, California).

Karalis, S., Karymbalis, E., Valkanou, K., Chalkias, C., Katsafados, P., Kalogeropoulos, K., Batzakis, V., Bofilios, A., 20I4. Assessment of the Relationships among Catchments' Morphometric Parameters and Hydrologic Indices. International Journal of Geosciences.5, I57I-1583

Lumbroso, D., Gaume, E., 20I2. Reducing the uncertainty in indirect estimates of extreme flash flood discharges. J. of Hydrol. 4I4-415, I6-30.

MoA. 2003. Tigray Regional State: A strategic plan for the sustainable development, conservation, and management of the woody biomass resources, final report. Ministry of Agriculture,Woody Biomass Inventory and Strategic Planning Project, Addis Ababa, Ethiopia.

National Weather Service, 1999. National Weather Service River Forecast System (NWSRFS) user's manual of Hydrol., Natl. Weather Serv., NOAA, Silver Spring, Md.

Nyssen J, Naudts J, De Geyndt K., Haile M, Poesen J, Moeyersons J, Deckers J, 2008. Soils and land use in the Tigray Highlands (Northern Ethiopia). Land Degrad. Develop.I9:250-274.

Nyssen, J., Clymans, W., Descheemaeker, K., Poesen, J., Vandecasteele, I., Vanmaercke, M., Zenebe, A., Van Camp, M., Haile, M., Haregeweyn, N., 20Io. Impact of soil and water conservation measures on catchment hydrological response-a case in north Ethiopia. Hydrological Processes 24, I8801895 .

Nyssen, J., Frankl, A., Zenebe, A., Deckers, J., \& Poesen, J. 2015. Land management in the northern Ethiopian highlands: local and global perspectives; past, present and future. Land Degradation \& Development, 26(7), 759-764.

Rantz, E.E.,I982. Measurement and computation of stream flow. Volume 2 Measurement of stage discharge U.S. Geological Survey Water Supply Paper: 2175.

Ruiz-Villanueva, V., Diez-Herrero, A., Stoffel, M., Bollschweiler, M., Bodoque, J.M., Ballesteros, J.A., 2010. Dendrogeomorphic analysis of flash floods in a small ungauged mountain catchment (Central Spain). Geomorphology. II $8,383-392$.

Schumm, S.A., 1956. Evolution of drainage systems and slopes in badlands at Perth Amboy, New Jersey. Geol Soc Am Bull 67, 597-646.

Tesfaalem G. Asfaha, Frankl, A., Mitiku Haile, Nyssen, J., 20I6. Catchment rehabilitation and hydrogeomorphic characteristics of mountain streams in the western Rift Valley escarpment of Northern Ethiopia. Journal of Land Degradation and Development, 27: 26-34.

Tesfaalem, G.A., Frankl, A., Mitiku, H., Amanuel, A.Z., Nyssen, J., 2015. Sediment flux dynamics as fingerprints of catchment rehabilitation: the case of western Rift Valley escarpment of North Ethiopia. Journal of Geomorphology, 250:220-235.

Tesfaalem, G.A., Frankl, A., Mitiku, H., Amanuel, A.Z., Nyssen, J., 2015. Determinants of peak discharge in steep mountain catchments-case of the Rift Valley escarpment of Northern Ethiopia. Journal of Hydrology, 529:1725-1739. DOI.org/I0.1016/j.jhydrol.2015.08.013

Villarini, G., Mandapaka, P.V., Krajewski, W.F., Moore, R.J., 2008. Rainfall and sampling uncertainties: A rain gauge perspective, J. Geophys. Res. II3, DirI02, doi: I0.1029/2007JDoog2I4.

Volkmann, T.H.M., Lyon, S.W., Gupta, H.V., Troch, P.A., 20Io. Multi-criteria design of rain gauge networks for flash flood prediction in semiarid catchments with complex terrain, Water Resour. Res. 46, WII554, DOI: I0.I029/2010WRoogI45.

Waltermeyer, S.D., 2008. Analysis of the Magnitude and Frequency of Peak Discharge and Maximum Observed Peak Discharge in New Mexico and Surrounding Areas, U.S. Geological Survey Scientific Investigations Report 2008-5519. 
WMO (World Meteorological Organization). 2008. Guide to Hydrological Practices, Volume I. Hydrology-From Measurement to. Hydrological Information, 6th ed. WMO, I68

Wohl, E.E., 2000. Mountain Rivers, Water Resources Monograph I4. American Geophysical Union: Washington, DC.

Wolman, M.G., I954. A method of sampling coarse riverbed material, Eos Trans. AGU, 35, 95I-956.

Yitbarek TW, Belliethathan S, Stringer LC. 2012. The onsite cost of gully erosion and cost-benefit of gully rehabilitation: a case study in Ethiopia. Land Degrad.Develop.23:157-I66. 